\title{
Concentration of trace elements in raw milk depending on the lactation period and age of cows
}

\author{
Alina Górska ${ }^{1}$, Krystyna Oprządek² \\ ${ }^{1}$ Chair of Cattle Breeding and Milk Evaluation, ${ }^{2}$ Institute of Chemistry, University of Natural Sciences \\ and Humanities in Siedlce, Poland
}

Received May 6, 2010

Accepted November 24, 2010

\begin{abstract}
Concentrations of iron, zinc, manganese and copper in milk from cows of Polish Holstein - Friesian Black-White breed kept on five farms located in the southern Podlasie region in Poland were determined and analysed depending on the lactation period and age of cows. Milk samples were taken separately from each cow, 18 samples from one farm. A total of 90 milk samples were taken. Cows were in three age classes (lactation number): 1, 2-3 and $>3$, and four lactation periods (duration): ): $\leq 100,101-200,201-305$ and $>305$ days). The concentration of trace elements in milk was determined using atomic absorption spectrometry method. Average concentrations of the elements in $1 \mathrm{~kg}$ of fresh milk were the following: iron $173 \pm 84 \mu \mathrm{g}$, zinc $3.6 \pm 0.9 \mathrm{mg}$, manganese $27 \pm 17 \mu \mathrm{g}$ and copper $40 \pm 23 \mu \mathrm{g}$. A relation between the age of cows and the concentrations of iron was observed. The lowest contents of iron $(145 \pm$ $72 \mu \mathrm{g} \cdot \mathrm{kg}^{-1}$ ) were observed in the milk from the youngest cows in their first lactation, whereas the highest contents $\left(217 \pm 70 \mu \mathrm{g} \cdot \mathrm{kg}^{-1}\right)$ were observed in the milk from the oldest cows above the third lactation. No relation between the age of cows and the concentrations of zinc, manganese and copper in milk was observed. Similarly, no significant differences between the contents of these elements in different lactation periods were observed. Study on factors influencing the concentrations of trace elements in cow milk were undertaken because researches on the subject are not numerous.
\end{abstract}

Iron, zinc, manganese, copper, milk, AAS, Poland

The content of all mineral elements in cow milk is $7.3 \mathrm{~g} \cdot \mathrm{l}^{-1}$ on average (Flynn 1992). The presence of the elements in milk may be of physiological (e.g. Fe, Co, Mo or Mn as building parts of vitamins or enzymes), technological (e.g. Fe or $\mathrm{Cu}$ ) or toxic (e.g. $\mathrm{Cd}$ and $\mathrm{Pb}$ ) character. The contents of both macro- and microelements in milk may vary significantly since they depend on various factors (Żmudzki et al. 1992; Zapletal et Bonczar 1993; Górska 2000; Dobrzański et al. 2005b; Swarup et al. 2005; Vidovic et al. 2005). The influence of some of them can be seen in a cow's organism - e.g. physiological or nutritional factors. It has been established that the concentrations of main mineral elements in milk such as $\mathrm{Ca}, \mathrm{P}, \mathrm{K}, \mathrm{Na}, \mathrm{Mg}, \mathrm{Cl}$, S vary depending on the cow's age, health condition, lactation period and the quality of feed (Pijanowski 1980). Much less research has been conducted on factors influencing the contents of microelements in milk: it has been stated that concentrations of microelements such as $\mathrm{Fe}, \mathrm{Zn}, \mathrm{Mn}, \mathrm{Cu}$ in milk ranged depending on the cow breed or milk production season (Barłowska 2007).

The aim of the present study was to determine the concentrations of $\mathrm{Fe}, \mathrm{Zn}, \mathrm{Mn}$ and $\mathrm{Cu}$ in milk depending on the age of cows and their lactation period.

\section{Materials and Methods}

The study material were milk samples taken over $24 \mathrm{~h}$ from cows of Polish-Holstein-Friesian black-white breed kept on five farms located in the southern Podlasie region in Poland. Cows were fed according to the full ration TMR feeding system. Samples of milk were taken separately from each cow. Cows were in three age

Address for correspondence:

Prof. Alina Górska

Chair of Cattle Breeding and Milk Evaluation

Prusa 14, 08-110 Siedlce, Poland

E-mail: agorska@uph.edu.pl

http://www.vfu.cz/acta-vet/actavet.htm 
classes (lactation number): 1, 2-3 and >3, and four lactation periods (duration): $\leq 100,101-200,201-305$ and > 305 days). A total of 90 milk samples were taken, 18 samples from one farm. At the same time information on the age of cows and lactation period was noted.

The trace elements in milk were determined by flame atomic absorption spectrometry method (FAAS) following the samples' digestion in an electric furnace at the temperature up to $450{ }^{\circ} \mathrm{C}$.

The validity of this method was checked by a parallel analysis of certified reference material (CRM 063 skimmed powder milk).

The results obtained were evaluated by standard statistical methods. Average values (x), standard deviation $( \pm \mathrm{SD})$, and median $(\mathrm{Me})$ were calculated. The statistical analysis considered three age classes (lactation number): $1,2-3$ and $>3$ and four lactation periods (duration): $\leq 100,101-200,201-305$ and $>305$ days). The relation between the age, lactation period and the concentrations of iron, zinc, manganese and copper in milk was calculated. The analysis was performed using one factor variant analysis and Duncan test.

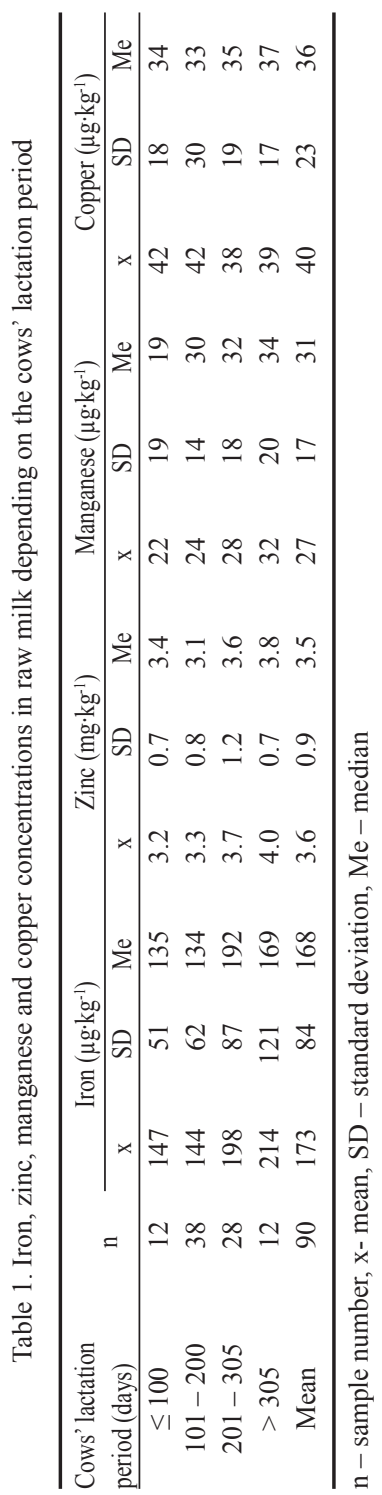

\section{Results and Discussion}

Results of the analysed trace elements depending on the lactation period and the age of cows are presented in Tables 1 and 2. The average contents of iron in $1 \mathrm{~kg}$ of analysed milk were $173 \pm 84 \mu \mathrm{g}$ and were similar to the results $\left(200 \mu \mathrm{g} \cdot \mathrm{kg}^{-1}\right)$ obtained in earlier studies conducted in this region in milk from single cows (Górska et Oprządek 2006) but lower than in milk pooled from the farms $\left(0.44 \mathrm{mg} \cdot \mathrm{l}^{-1}\right)$ (Górska et Oprządek 2004). Higher iron contents $0.62 \mathrm{mg} \cdot \mathrm{kg}^{-1}$, and $0.44 \mathrm{mg} \cdot \mathrm{l}^{-1}$ for pooled milk were determined in ZgorzelecBogatynia region (Żmudzki et al. 1992) and in southern Poland (Zapletal et Bonczar 1993), respectively. The average contents of iron in pooled milk in the years 20012003 in Poland were $0.32 \mathrm{mg} \cdot \mathrm{kg}^{-1}$ (Szkoda et al. 2004).

A significant relation $(P \leq 0.05)$ between the age of a cow (lactation number) and the content of iron in milk was observed. The lowest iron concentration (145 $\left.\pm 72 \mu \mathrm{g} \cdot \mathrm{kg}^{-1}\right)$ was observed in milk from the youngest cows in their first lactation. The highest concentration $\left(217 \pm 70 \mu \mathrm{g} \cdot \mathrm{kg}^{-1}\right)$ was observed in milk from the oldest cows ( $>3$ lactation).

Considering the concentrations of iron in cow milk in different lactation periods it was noted that lower contents of iron, i.e. $147 \pm 51 \mu \mathrm{g} \cdot \mathrm{kg}^{-1}$ and $144 \pm 62 \mu \mathrm{g} \cdot \mathrm{kg}^{-1}$ were observed in milk from cows whose lactation lasted $\leq 100$ and 101-200 days compared to the other cows with a lactation period 201305 and $>305$ days whose milk contained iron at the amount of $198 \pm 87$ to $214 \pm 121 \mu \mathrm{g} \cdot \mathrm{kg}^{-1}$, respectively. However, these differences were not significant.

The average contents of zinc in analysed milk were $3.6 \pm$ $0.9 \mathrm{mg} \cdot \mathrm{kg}^{-1}$ and were similar to zinc concentrations of 3.73 $\mathrm{mg} \cdot \mathrm{kg}^{-1}$ in fresh milk observed by Szkoda et Żmudzki 2002 in the years 1998-2000 in a monitoring study conducted in the whole Poland. Similar contents of zinc $\left(3307 \mu \mathrm{g} \cdot \mathrm{l}^{-1}\right)$ in milk from 25 cows were observed also by Dobrzański et al. 2005a. Higher contents of zinc in milk (falling within a range of 4.1 to $5.28 \mathrm{mg} \cdot \mathrm{kg}^{-1}$ ) in other regions in Poland were observed by Górski et Nikodemska 1991, Żmudzki et al. 1992, Międzobrodzka et al. 1995. Rodrigues et al. 2001 observed also a higher zinc contents $\left(4.41 \mathrm{mg} \cdot \mathrm{kg}^{-1}\right)$ in fresh 


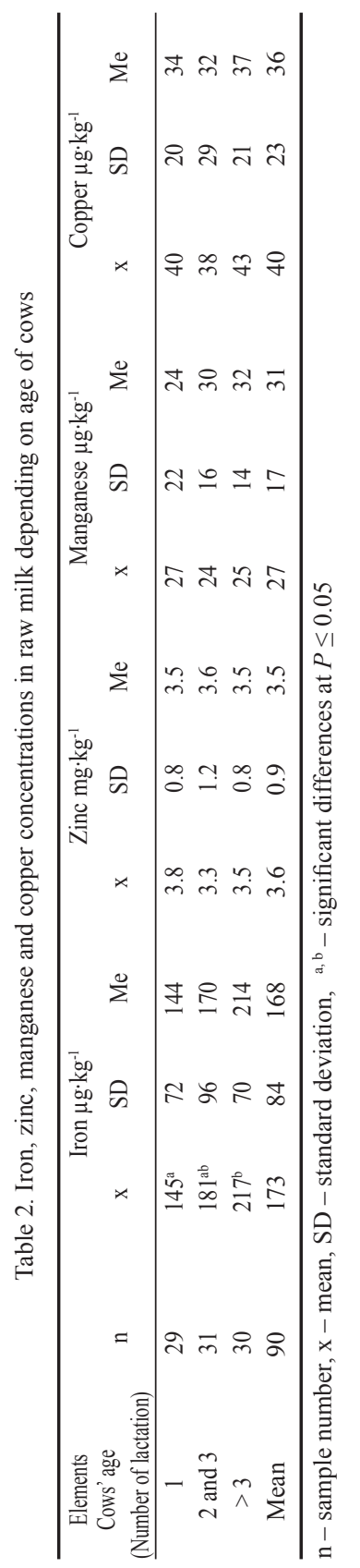

milk on Canary Islands, Spain, whereas lower concentrations of zinc $\left(2016 \mu \mathrm{g} \cdot \mathrm{kg}^{-1}\right)$ were observed in milk from cows in Calabria, Italy (Licata et al. 2004).

The average contents of manganese in analysed milk reached $27 \pm 17 \mu \mathrm{g} \cdot \mathrm{kg}^{-1}$ and those of copper reached $40 \pm 23$ $\mu \mathrm{g} \cdot \mathrm{kg}^{-1}$. Higher contents of manganese in milk were observed in Poland by Zapletal et Bonczar $1992\left(38.8 \mu \mathrm{g} \cdot \mathrm{l}^{-1}\right)$ but Dobrzański et al. 2005a reported $74.3 \mu \mathrm{g} \cdot \mathrm{l}^{-1}$. The contents of copper in analysed milk fell within the range of 0.01 to $0.19 \mathrm{mg} \cdot \mathrm{kg}^{-1}$ as reported by many authors in Poland (Górski et Nikodemska 1991; Żmudzki et al. 1992, Zapletal et Bonczar 1993; Dobrzański et al. 2005a).

No relation was observed between the age of cows (lactation number) and the contents of zinc, manganese and copper in milk. Depending on the age of cows the concentrations of zinc varied from $3.3 \pm 1.2$ to $3.8 \pm 0.8 \mathrm{mg} \cdot \mathrm{kg}^{-1}$, the concentrations of manganese ranged from $24 \pm 16$ to $27 \pm 22 \mu \mathrm{g} \cdot \mathrm{kg}^{-1}$ and the concentrations of copper ranged from $38 \pm 29$ to $43 \pm 21$ $\mu \mathrm{g} \cdot \mathrm{kg}^{-1}$.

Together with the lactation period progressing from $\leq 100$ to $>305$ days the concentrations of zinc increased from 3.2 \pm 0.7 to $4.0 \pm 0.7 \mathrm{mg} \cdot \mathrm{kg}^{-1}$ and the contents of manganese increased from $22 \pm 19$ to $32 \pm 20 \mu \mathrm{g} \cdot \mathrm{kg}^{-1}$. These differences, however, were non-significant. Similarly, no relation between the lactation period and the concentrations of copper in milk was observed. The contents of copper in milk during lactation remained at $38 \pm 19$ to $42 \pm 30 \mu \mathrm{g} \cdot \mathrm{kg}^{-1}$.

\section{References}

Barłowska JB 2007: Nutritional value and technological usability of milk from cows of 7 breeds maintained in Poland, Rozpr Hab Zesz Nauk AR Lublin z. 321

Dobrzański Z, Górecka H, Opaliński S, Chojnacka K, Kołacz R 2005a: Trace and ultra-trace elements in cow's milk and blood. Med Wet 61: 301-304 (in Polish)

Dobrzański Z, Kołacz R, Górecka H, Chojnacka K, Bartkowiak A 2005b: The content of microelements and trace elements in raw milk from cows in the Silesian Region. Polish J Environ Stud 14: 685-689

Flynn A 1992: Minerals and trace elements in milk. Adv. in Food and Nut. Res. 36: 209-252

Górska A 2000: Calcium and magnesium content in cow milk from farms in the Podlasie region. Rocz Nauk Zoot 6: 42-45 (in Polish)

Górska A, Oprządek K 2004: Iron content in cow milk from farms of South Podlasie region. Rocz PZH 55: 67-69 (in Polish with English abstract)

Górska A, Oprządek K 2006: Levels of trace elements in cow milk from farms of Southern Podlasie Region. Polish J Environ Stud 15: 269-272

Górski J, Nikodemska J 1991: Content of lead, cadmium, zinc and copper in cow milk from some area of Katowice district. Przegl Mlecz 1: 18-19 (in Polish)

Licata P, Trombetta D, Cristani M, Giofre F, Martino D, Calo M, Naccari F 2004: Levels of "toxic" and "essential" metals in samples of bovine milk from various dairy farms in Calabria Italy. Environ International 30: $1-6$

Międzobrodzka A, Sikora E, Cieślik E 1995: The content of selected minerals and some heavy metals in food products from southern Poland. Part II, Milk and dairy products. Zesz Nauk AR Kraków, Food Tech 7: 89-94

Pijanowski E 1980: Dairy chemistry and technology. Warszawa : 107-112 (in Polish) 
Rodriguez EM, Sanz Alaejos M, Diaz Romero C 2001: Mineral concentrations in cow's milk from the Canary Island. J of Food Comp and Anal 14: 419-430

Swarup D, Patra RC, Naresh R, Kumar P, Shekhar P 2005: Blood lead levels in lactating cows reared around polluted localities; Transfer of lead into milk. Sci Total Environ 349: 67-71

Szkoda J, Żmudzki J 2002: Zinc in animal tissues and food of animal origin. Zesz Nauk Polish Acad Sci 33: 457-463 (in Polish with English abstract)

Szkoda J, Żmudzki J, Grzebalska A 2004: Iron in animal tissues: milk. Rocz PZH 55: 61-66 (in Polish)

Vidovic M, Sadibasica A, Cupic S, Lausevic M 2005: Cd and and Zn in atmospheric deposit, soil, wheat and milk. Environ Res 97: 26-31

Zapletal P, Bonczar G 1993: The content of minerals and some trace elements in raw milk from Krakow area. Przegl Mlecz 11: 298-300 (in Polish)

Żmudzki J, Juszkiewicz T, Niewiadomska A, Szkoda J, Semeniuk St, Gołębiowski A, Szyposzyński K 1992: Chemical contamination of cattle, milk and eggs in Zgorzelecko-Bogatyński area. Med Wet 48: 213-215 (in Polish) 